\title{
Stabilność finansowa gmin wiejskich w Polsce
}

\author{
Agnieszka Kozera*
}

\begin{abstract}
Prawidtowe funkcjonowanie gmin, jako podstawowych podmiotów sektora samorzadowego, zwiazane jest bezpośrednio z koniecznościa utrzymania przez nie stabilności finansowej. Jest ona definiowana jako zdolność do petnienia przez JST przypisanych im zadań $w$ sposób ciagty $i$ efektywny, niezaleznie od nieoczekiwanych i niekorzystnych zaburzeń o znacznej skali. Wśród ogótu gmin największa zbiorowość tworza gminy wiejskie. Wyróżnia je zróżnicowany charakter petnionych funkcji, od gmin wiejskich o typowo rolniczym charakterze po gminy wiejskie petniace funkcje rezydencjalno-ustugowe. Po wejściu Polski w struktury europejskie to wtaśnie obszarom wiejskim, ich problemom, perspektywom, a także zagrożeniom rozwoju poświęca sie wiele uwagi. Coraz więcej uwagi poświęca się także kondycji finansowej tych podmiotów, będącej ważnym elementem analizy zjawiska ich stabilności finansowej. Celem artykutu jest analiza zjawiska stabilności finansowej gmin wiejskich, między innymi na podstawie analizy zmian poziomu ich wtasnego potencjatu dochodowego, wyniku finansowego oraz zjawiska zadtużenia w latach 2007-2014. Badania przeprowadzono na podstawie danych pochodzacych z Gtównego Urzędu Statystycznego oraz Ministerstwa Finansów.
\end{abstract}

Słowa kluczowe: stabilność finansowa, bezpieczeństwo finansowe, własny potencjał dochodowy, zadłużenie, dystres finansowy, gminy wiejskie.

Nadesłany: 13.03.17 | Zaakceptowany do druku: 01.05.17

\section{Financial stability of rural communes in Poland}

The proper functioning of the communes, as the basic units of local government sector, is directly related to the necessity of maintaining their financial stability. It is defined as the ability of communes to perform their tasks on a continuous and effective basis, regardless of unexpected or unfavorable disturbances of a large scale. Among the total communes, the largest group consists of rural communes. They are distinguished by the varied nature of the functions they perform, from rural communes with typically agricultural character to rural communes with residential and service nature. After Poland's access to European structures, problems and perspectives of development of rural areas is paid a lot of attention. More and more attention is paid also to the financial condition of these entities, which is an important element of the analysis of the phenomenon of their financial stability. The aim of the article is to analyze the phenomenon of financial stability of rural communes, inter alia on the basis of an analysis of changes in the level of their own income potential, financial result and phenomenon of debt in years 2007-2014. The study was based on data from the Central Statistical Office and the Ministry of Finance.

\footnotetext{
* Agnieszka Kozera, dr - Wydział Ekonomiczno-Społeczny, Katedra Finansów i Rachunkowości, Uniwersytet Przyrodniczy w Poznaniu.

Adres do korespondencji: Wydział Ekonomiczno-Społeczny, Katedra Finansów i Rachunkowości, Uniwersytet Przyrodniczy w Poznaniu, ul. Wojska Polskiego 28, 60-637 Poznań; e-mail: akozera@up.poznan.pl.
} 
Keywords: financial stability, financial security, own potential income, debts, financial distress, rural communes.

Submitted: 13.03.17 | Accepted: 01.05.17

JEL: H72, R51

\section{Wstęp}

Podstawowym celem funkcjonowania jednostek samorzadu terytorialnego (JST), w tym przede wszystkim gmin, jest zapewnienie jak najwyższego poziomu życia, a także kreowanie rozwoju lokalnego. Jego realizacja wymaga zapewnienia stałego dopływu środków niezbędnych do finansowania zadań wykonywanych przez podmioty sektora samorządowego, o charakterze zarówno bieżącym, jak i inwestycyjnym, niezależnie od nieoczekiwanych i niekorzystnych zaburzeń o znacznej skali. Tak pojmowaną zdolność do pełnienia przez JST przypisanych im zadań w sposób ciągły i efektywny m.in. Przygodzka (2014) określa mianem stabilności finansowej. Podejmowanie działań mających na celu zapewnienie stabilności finansowej, zgodnie $\mathrm{z}$ ustawą o finansach publicznych (art. 86, 260), należy do głównych zadań władz samorzadowych każdego szczebla. W tym celu JST powinny między innymi prowadzić gospodarkę budżetową zgodnie $\mathrm{z}$ regułami zawartymi w tejże ustawie.

Do niedawna pojęcie stabilności finansowej rozpatrywane było głównie w odniesieniu do podmiotów sektora finansowego. Wzrost zainteresowania zjawiskiem stabilności finansowej w odniesieniu do JST jest niewątpliwie skutkiem ostatniego kryzysu finansowego, który wpłynął na ich funkcjonowanie (por. Poniatowicz, 2014). Jak zauważa bowiem Filipiak (2016), zagadnienie stabilności finansowej właśnie tych podmiotów było niedoceniane w warunkach dobrej koniunktury gospodarczej i stabilnego wzrostu poziomu własnego potencjału dochodowego JST. Obecnie podejmuje się coraz częściej analizy zjawisk determinujących stabilność finansową podmiotów sektora samorządowego, a zwłaszcza gmin (por. Klank, 2014; Kata, 2015; Dylewski, 2016).

Wśród ogółu gmin w Polsce wyróżnia się trzy ich typy administracyjne, tj. gminy miejskie, wiejskie oraz miejsko-wiejskie. W ich strukturze dominuja gminy wiejskie, których w 2016 roku funkcjonowało 1559 i stanowiły one $63 \%$ ogółu gmin. Gminy wiejskie zamieszkuje $11 \mathrm{mln}$ osób, czyli blisko 30\% ogółu społeczeństwa. Wzrasta także potencjał demograficzny i gospodarczy tych podmiotów, zwłaszcza gmin wiejskich znajdujacych sie blisko wieksszych ośrodków miejskich (tzw. obszarów metropolitalnych). Gminy wiejskie wyróżniają się jednak najwyższym stopniem zróżnicowania pod katem poziomu rozwoju społecznogospodarczego i pełnionych przez nie funkcji (od gmin typowo rolniczych po gminy reprezentujące typ rezydencjalno-usługowy, które całkowicie zatraciły wiejski charakter) (por. Kozera i Wysocki 2015, Monitoring rozwoju obszarów wiejskich 2016). W ostatnich latach, a zwłaszcza po wejściu Polski w struktury europejskie, ich problemom, perspektywom, a także zagrożeniom rozwoju poświęca się wiele uwagi (por. Bański, 2014, Hadyński, 2015, Heffner i Klemens 2016). Coraz więcej uwagi poświęca się także kondycji finansowej tych podmiotów (por. Bieniasz, Gołaś i Łuczak, 2014; Kozera, Głowicka-Wołoszyn i Wysocki, 2015; Standar i Kozera, 2016).

Głównym celem autorki artykułu jest analiza zjawiska stabilności finansowej gmin wiejskich w Polsce w latach 2007-2014. Ze względu na wieloaspektowość badanego zjawiska analizie poddano kształtowanie się wysokości dochodów własnych, wyniku finansowego budżetów, a także zjawiska zadłużenia gmin wiejskich na tle pozostałych typów administracyjnych. Badania empiryczne przeprowadzono na podstawie danych pochodzących z Głównego Urzędu Statystycznego (Bank Danych Lokalnych) oraz Ministerstwa Finansów (Wskaźniki do oceny sytuacji finansowej jednostek samorządu terytorialnego), które przetworzono z wykorzystaniem podstawowych metod statystyki opisowej.

\section{Istota stabilności finansowej gmin}

Pojęcie stabilności finansowej w literaturze przedmiotu pojawiło się stosunkowo niedawno, głównie w kontekście makroeko- 
nomicznym w odniesieniu do sektora finansowego. Narodowy Bank Polski stabilność systemu finansowego definiuje jako stan, w którym system pełni swoje funkcje w sposób ciągły i efektywny, nawet w przypadku wystąpienia nieoczekiwanych i niekorzystnych zaburzeń o znacznej skali (Raport o stabilności systemu finansowego..., 2016). Ze względu na wielowymiarowość tego zjawiska trudno jest podać konkretny zestaw „wskaźników” opisujących stabilność finansową. W literaturze światowej, jak podają Alińska i Wasiak (2014), badając zjawisko stabilności finansowej, analizie poddaje się czynniki konieczne do spełnienia, aby stwierdzić, że system jest stabilny (chociażby utrzymanie płynności finansowej według Crokietta (1997)), bądź dokonuje się próby doprecyzowania terminu niestabilności finansowej oraz przyczyn jego powstania (Mishkin, 2000).

Stabilność finansowa, zwłaszcza w warunkach ogólnoświatowego kryzysu finansowego, jak podkreśla Griffith-Jones (2003), można uznać za swojego rodzaju „dobro" publiczne, które jest niezbędne dla osiaggnięcia międzynarodowej efektywności finansowej. Stabilność finansowa, jak zauważają Flejterski i in. (2012), ma fundamentalne znaczenie dla wszystkich podmiotów wyróżnionych na gruncie nauki o finansach - od globalnego i międzynarodowego do poziomu mikro. Utrzymanie stabilności finansowej (lecz przybliżonej niż absolutnej) jest więc wyzwaniem dla wspólczesnych finansów, na poziomie nie tylko poszczególnych państw, lecz także pojedynczych podmiotów, np. gospodarstw domowych (por. Kozera, Stanisławska i Głowicka-Wołoszyn, 2016), przedsiębiorstw (por. Bieniasz i Czerwińska-Kayzer, 2016), ale również podmiotów sektora finansów publicznych, w tym jednostek samorządu terytorialnego. Stabilność finansowa JST, stanowiąc element stabilności finansowej (bezpieczeństwa finansowego) ${ }^{1}$ sektora finansów publicznych, warunkuje możliwość zaspokojenia bieżących i przyszłych potrzeb społeczności lokalnych, jak również stanowi fundament zrównoważonego rozwoju społeczno-gospodarczego regionu. Zarówno dochody, jak i wydatki ogółu podmiotów sektora samorządowego stanowią bowiem ponad jedną czwartą dochodów i wydatków całego sektora finansów publicznych (Gospodarka finansowa jednostek samorzadu terytorialnego 2014, Roczne wskaźniki makroekonomiczne, dostęp: 26.02.2017).

Prawidłowe funkcjonowanie JST, w tym gmin jako podstawowych podmiotów sektora samorzadowego, związane jest bezpośrednio z koniecznością utrzymania przez nie stabilności finansowej. Według Filipiak (2016) wzrost zainteresowania zjawiskiem stabilności finansowej podmiotów sektora samorządowego jest skutkiem ostatniego kryzysu finansowego. Zagadnienie stabilności finansowej właśnie tych podmiotów było niedoceniane w warunkach dobrej koniunktury gospodarczej i stabilnego wzrostu poziomu własnego potencjału dochodowego JST. Obecnie coraz częściej podejmuje się analizy zjawiska stabilności finansowej JST, a zwłaszcza gmin w różnym zakresie i z różnych punktów widzenia (por. Przychodzka, 2014; Klank, 2014; Kata, 2015; Dylewski, 2016; Filipiak, 2016; Standar i Kozera 2016).

Termin stabilności finansowej podmiotów sektora finansów publicznych w polskich aktach prawnych nie jest jednak sprecyzowany. W najważniejszym akcie prawnych, tj. w Konstytucji RP, termin stabilności finansowej nie jest w ogóle definiowany. $\mathrm{Z}$ kolei w ustawie o finansach publicznych można odnaleźć kilkanaście reguł dotyczących prowadzenia przez JST gospodarki budżetowej, których stosowanie zapewnia zachowanie stabilności finansowej. Wśród nich występują zasady utrzymania równowagi budżetowej oraz konieczności finansowania deficytu budżetowego (art. 217). Ważnym elementem prowadzenia odpowiedniej gospodarki budżetowej przez JST jest także stanowienie rezerw ogólnej i celowej (art. 222). Rezerwy zabezpieczają bowiem jednostkę przed negatywnymi skutkami ryzyka. Rezerwa ogólna w budżetach JST ma charakter obowiazkowy i może być przeznaczona na dowolny wydatek danej jednostki, związany z realizacją jej zadań, którego nie można było przewidzieć w dniu uchwalania budżetu. Zgodnie $\mathrm{z}$ ustawa o finansach publicznych w budżecie JST tworzy się rezerwę ogólną, w wysokości nie niższej niż $0,1 \%$ i nie wyższej niż $1 \%$ wydatków budżetu. $\mathrm{Z}$ kolei rezerwy celowe $\mathrm{w}$ budżetach JST mogą być tworzone na wydatki, których szczegółowy podział na pozycje klasyfikacji budżetowej nie może być dokonany w okresie opracowywania budżetu JST, na wydatki związane $\mathrm{z}$ realizacją programów finanso- 
wanych z udziałem środków, o których mowa w ustawie o finansach publicznych lub też gdy odrębne ustawy tak stanowią. Suma rezerw celowych przeznaczonych na wydatki, których szczegółowy podział na pozycje klasyfikacji budżetowej nie może być dokonany w okresie opracowywania budżetu JST oraz na wydatki określone w odrębnych ustawach, nie może przekroczyć 5\% wydatków budżetu JST. Zgodnie $\mathrm{z}$ art. 86 oraz 260 podmioty sektora finansowego zobowiązane są także do podejmowania działań zmierzających do zachowania stabilności finansowej.

Zdaniem Filipiak (2016) stabilność finansowa JST jest stanem, który pozwala na realizację przypisanych im funkcji, transakcji dotyczących zadań JST z gwarancja, że zgodnie $\mathrm{z}$ art. 44 ust. 3 ustawy o finansach publicznych zostaną one uregulowane i nie wpłyną w sposób negatywny na budżet, a także na efektywną alokację zasobów finansowych i rzeczowych oraz skuteczną identyfikacje i zarzadzanie ryzykiem. W ocenie zjawiska stabilności finansowej podmiotów sektora samorządowego istotna jest więc analiza ryzyka i zagrożeń mających wpływ zarówno na wysokość dochodów, jak i wydatków budżetowych JST. Zgodnie $\mathrm{z}$ art. 86 ust. 2 ustawy o finansach publicznych JST mają obowiązek prowadzenia czynności związanych z zarządzaniem ryzykiem. W działalności JST występuje kilka kategorii ryzyka, tj. systematyczne (ogólne) i specyficzne (zwane także szczegółowym lub operacyjnym). W przypadku pierwszej kategorii ryzyka jest ono wynikiem uwarunkowań zewnętrznych, na które JST nie ma wpływu, a więc nie podlega ono kontroli. Filipiak (2011) uważa, że źródłami ryzyka systematycznego są zmiany koniunktury gospodarczej, sytuacji społeczno-polityczno-ekonomicznej, przepisów prawnych itp. Z kolei ryzyko specyficzne uwarunkowane jest czynnikami mikroekonomicznymi, czyli tkwiacymi wewnatrz JST i jej najbliższym otoczeniu. Przykładem tego może być nadmierny poziom zadłużenia JST, który przekracza indywidualną zdolność kredytową i brak zdolności do wywiązywania się ze swoich zobowiązań. Filipiak (2016) w ramach ryzyka specyficznego wyróżnia m.in. ryzyko jakości zarządzania, ryzyko płatności oraz ryzyko kredytowe.

Dla utrzymania stabilności finansowej gmin niezwykle ważne jest posiadanie przez te podmioty stabilnych źródeł dochodów. Jak zauważają bowiem Lubińska i in. (2007), analiza budżetu JST w oparciu o osiągane dochody o charakterze stabilnym pozwala określić długookresowa zdolność samorządów do finansowania realizowanych przez nie zadań. Stabilne źródła dochodów bieżących to takie, które zapewniają cykliczne, w bardzo wysokim stopniu przewidywalne, wpływy do budżetu gmin oraz nie wygasają po upływie krótkiego okresu. Punktem wyjścia do analizy zjawiska stabilności finansowej gmin staje się więc kategoria własnego potencjału dochodowego, do którego zalicza się większość źródeł dochodów własnych gmin. Gminy zostały wyposażone w tzw. władztwo podatkowe, to znaczy w uprawnienia do podejmowania decyzji w zakresie ustalania wysokości podatków i opłat lokalnych. Władztwo to ma charakter kształtowania obciążeń podatkowych, a nie stanowienia podatków. Jak zauważa Filipiak (2015), problem stanowienia polityki podatkowej gmin jest nie tylko ważnym aspektem posiadanego przez te podmioty władztwa podatkowego, ale również elementem strategicznym dla celów budowania ich stabilności finansowej w krótkim i długim okresie.

Istotnym problemem dla utrzymania stabilności finansowej zarówno całego sektora finansów publicznych, jak i poszczególnych jednostek samorządu terytorialnego jest rosnący poziom zadłużenia. Do tej pory bezpieczeństwo finansowe podmiotów sektora samorządowego analizowane było najczęściej w kontekście właśnie poziomu ich zadłużenia. Dług JST jest częścią państwowego długu publicznego, dlatego zarządzanie bezpieczeństwem finansowym wymaga podejmowania decyzji odnośnie do maksymalnego poziomu zadłużenia tych podmiotów. Stanowią je przede wszystkim ograniczenia prawne, które mają wpływ na poziom zadłużenia JST, w szczególności na poziom zobowiązań z tytułu obsługi długu i finansów przeznaczonych na regulowanie tych zobowiązań (Jastrzębska, 2009). Do roku 2013 obowiązywały, zgodnie z ustawą o finansach publicznych, dwa ilościowe pułapy zadłużenia ${ }^{2}$. Ustawowe limitowanie poziomu zadłużenia JST tylko poprzez odniesienie się do poziomu dochodów (i jednocześnie brak powiązania z sytuacją ekonomiczną jednostki) groziło zadłużaniem sie JST ponad jej faktyczne możliwości spłaty długu, przy jednoczesnym 
formalnym dotrzymaniu granic zadłużenia. W 2014 roku w miejsce ilościowych limitów wprowadzono więc indywidualny wskaźnik poziomu zadłużenia JST $^{3}$, uwzględniający indywidualne zdolności każdej jednostki do spłaty zobowiązań (Romanowicz, 2014). Jak wynika z badań przeprowadzonych przez Korolewską i Marchewkę-Bartkowiak (2011), nowe rozwiązania, wyznaczające indywidualne granice zadłużania się samorządów, urealniają określenie bezpiecznego poziomu długu, a tym samym w wyższym stopniu warunkują stabilność finansową tych podmiotów.

Nadmierny poziom zadłużenia nie tylko prowadzi do destabilizacji gospodarki finansowej, lecz także wpływa bezpośrednio na skuteczność wykonywania zadań przez podmioty sektora finansów publicznych, w tym przez gminy. Skala tych problemów szczególnie szybko i mocno nasila się w okresie spowolnienia gospodarczego. Sytuacja ta oznacza bowiem zmniejszenie wpływów do budżetów gmin z tytułu podatków (w tym $\mathrm{z}$ tytułu udziałów w podatkach dochodowych stanowiacych dochód budżetu państwa) i opłat lokalnych. W celu utrzymania stabilności zarówno całego sektora finansów publicznych, jak i JST ważne jest monitorowanie i ograniczenie poziomu zadłużenia. Stabilność finansowa podmiotów sektora finansowego według Dylewskiego (2016), w perspektywie finansowej 2014-2020, wyrażona będzie bowiem poprzez zdolność tych podmiotów do realizacji obligatoryjnych zadań oraz zdolność do obsługi zadłużenia $\mathrm{z}$ jednoczesna trwałością możliwości realizacji zamierzeń rozwojowych (szczególnie tych związanych $\mathrm{z}$ absorpcja środków UE).

Znacznie rzadziej w ocenie bezpieczeństwa finansowego JST w Polsce bierze się pod uwagę zjawisko „fiskalnego dystresu”. Pojęcie to definiuje się między innymi jako nierównowagę między posiadanymi zasobami finansowymi (dochodami) a potrzebami (wydatkami) (Avoiding local government, 2000). Podstawowym kryterium oceny dystresu finansowego, czyli stopnia zagrożenia bezpieczeństwa finansowego JST, jest długotrwałe (ciągłe i minimum trzyletnie) wystepowanie ujemnego wyniku budżetowego $\mathrm{z}$ jednoczesnym wysokim deficytem, którego skumulowany poziom w tym okresie w relacji do dochodów ogółem przekracza 5\% (Trussel i Patric, 2009). Wielu autorów, m.in. Clark i Appleton (Clark 2004), termin fiskalnego stresu określiło jako brak adaptacji samorządu do zmieniającego się otoczenia. Zjawisko to może wystąpić między innymi w sytuacjach zmniejszenia się dochodów jednostek samorzadowych bez równoczesnego ograniczenia popytu na usługi publiczne, badź też w przypadku zwiększenia zapotrzebowania mieszkańców na usługi, podczas gdy samorząd nie jest w stanie wygenerować wyższych dochodów (Chapman, 1999).

Podmioty sektora finansów publicznych, w tym samorządy gmin, w mniejszym stopniu zagrożone są utratą zdolności do kontynuowania działalności. Nie podlegają one bowiem przepisom związanym z upadłościa podmiotu gospodarczego. Warto mieć jednak na uwadze, że mogą one zostać zlikwidowane, gdy ich dalsza działalność będzie zagrażała płynności finansowej i wypłacalności organu nadrzędnego. Fiskalny dystres, jak zauważają Kloha, Weissert i Kleine (2005), w skrajnej postaci może doprowadzić nawet do sytuacji krytycznych, w których JST nie są w stanie realizować nawet podstawowych świadczeń. Szacowanie zagrożeń związanych z wystąpieniem zjawiska dystresu finansowego nie jest zadaniem prostym, ale istotną kwestią jest prowadzenie badań w tym zakresie i bieżąca identyfikacja potencjalnych zagrożeń.

Władze lokalne posiadają instrument, który daje możliwość skutecznego zarzadzania finansami jednostki w perspektywie długiego okresu. W kontekście oceny długookresowej stabilności finansowej jednostek samorzadu terytorialnego istotne znaczenie mają dane zawarte $\mathrm{w}$ wieloletnich prognozach finansowych. Wieloletnia prognoza finansowa jest bowiem narzędziem pozwalającym planować indywidualny rozwój każdej społeczności lokalnej. Prognozy te powinien cechować realizm. Powinna ona wskazywać warunki do prowadzenia racjonalnej, odpowiedzialnej i stabilnej polityki finansowej, a także uwzględniać zdarzenia, które mają lub mogą mieć wpływ na gospodarkę finansową jednostek samorządu terytorialnego.

Reasumując: stabilność finansowa podmiotów sektora samorządowego jest uwarunkowana czynnikami zarówno wewnętrznymi, jak i zewnętrznymi. Czynniki wewnętrzne destabilizacji finansowej JST, jak zauważa m.in. Poniatowicz (2016) związane są z dysfunkcjami z zakresie prowadzonej gospodarki finansowej władz samorządowych (m.in. nad- 
mierne wydatki JST niedostosowane do poziomu własnego potencjału dochodowego, nieefektywna polityka inwestycyjna i zadłużeniowa oraz brak odpowiedniej polityki zarządzania ryzykiem w kontekście zapewniania stabilności finansowej JST). Z drugiej strony wśród czynników zewnętrznych, mających wpływ na stabilność finansową JST, wyróżnia się m.in. niestabilność warunków ekonomicznych, niestabilne otoczenie prawne i związane $\mathrm{z}$ tym częste zmiany legislacyjne destabilizujące systemy finansowe tych podmiotów (Poniatowicz, 2016).

\section{Analiza stabilności finansowej} gmin wiejskich na tle pozostałych typów administracyjnych w Polsce w latach 2007-2015

Przez stabilność finansową rozumie się zdolność podmiotów sektora samorządowego zarówno do finansowania realizowanych zadań własnych, jak i do regulowania zobowiązań finansowych. Zjawisko to do tej pory było analizowane w różnym zakresie oraz z różnych punktów widzenia. Stabilność finansowa gmin utożsamia sie między innymi ze stabilnością źródeł dochodów własnych tych podmiotów. Gminy, w celu realizacji przypisanych ich zadań, zostały wyposażone w tzw. dochody własne, do których zalicza się m.in. podatki i opłaty lokalne, udziały w podatkach dochodowych stanowiących dochód budżetu państwa oraz dochody $\mathrm{z}$ majątku. W tabeli 1 przedstawiono kształtowanie się wysokości dochodów własnych gmin wiejskich na tle pozostałych typów gmin w latach 2007-2015. Własny potencjał dochodowy gmin wiejskich ogółem, kwantyfikowany wysokością dochodów własnych per capita jest niższy w relacji do gmin miejsko-wiejskich i miejskich. W 2015 roku w przeciętnej gminie wiejskiej dochody własne wynosiły w ujęciu nominalnym 1501,4 zł per capita, podczas gdy w przeciętnej gminie miejsko-wiejskiej i miejskiej odpowiednio 1713,7 i 1990,5 zl per capita. W badanym okresie to jednak

Tabela. 1. Poziom dochodów własnych per capita gmin w układzie typów administracyjnych $w$ latach 2007-2015

\begin{tabular}{|c|c|c|c|c|c|c|c|c|c|c|}
\hline \multicolumn{2}{|r|}{ Wyszczególnienie } & 2007 & 2008 & 2009 & 2010 & 2011 & 2012 & 2013 & 2014 & 2015 \\
\hline \multicolumn{11}{|c|}{ Nominalne dochody własne w zł per capita } \\
\hline \multirow{3}{*}{ 駡 } & wiejskie & 849,7 & 986,3 & 972,9 & 1048,1 & 1131,9 & 1212,1 & 1300,1 & 1416,3 & 1501,4 \\
\hline & miejsko-wiejskie & 1063,2 & 1234,1 & 1205,7 & 1271,0 & 1361,7 & 1444,3 & 1530,1 & 1643,7 & 1713,7 \\
\hline & miejskie a) & 1365,3 & 1562,0 & 1503,1 & 1560,5 & 1637,0 & 1701,6 & 1785,9 & 1931,0 & 1990,5 \\
\hline \multicolumn{2}{|c|}{$\begin{array}{l}\text { miasta na prawach } \\
\text { powiatu }\end{array}$} & 2416,6 & 2704,2 & 2622,4 & 2713,3 & 2850,7 & 2971,4 & 3160,9 & 3392,3 & 3542,7 \\
\hline \multicolumn{2}{|c|}{ metropolie b) } & 2434,9 & 2724,2 & 2677,4 & 2742,6 & 2924,9 & 3083,4 & 3267,9 & 3550,4 & 3638,6 \\
\hline \multicolumn{11}{|c|}{ Realne dochody własne w zł per capita (według cen stałych z 2007 roku) } \\
\hline \multirow{3}{*}{ 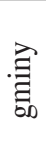 } & wiejskie & 849,7 & 946,5 & 902,1 & 947,2 & 980,8 & 1012,8 & 1076,7 & 1172,9 & 1254,6 \\
\hline & miejsko-wiejskie & 1063,2 & 1184,4 & 1118,0 & 1148,6 & 1179,9 & 1206,8 & 1267,1 & 1361,2 & 1432,0 \\
\hline & miejskie & 1365,3 & 1499,1 & 1393,7 & 1410,3 & 1418,5 & 1421,8 & 1478,9 & 1599,1 & 1663,3 \\
\hline \multicolumn{2}{|c|}{$\begin{array}{l}\text { miasta na prawach } \\
\text { powiatu }\end{array}$} & 2416,6 & 2595,2 & 2431,6 & 2452,1 & 2470,1 & 2482,8 & 2617,6 & 2809,2 & 2960,4 \\
\hline \multicolumn{2}{|c|}{ Metropolie } & 2434,9 & 2614,4 & 2482,6 & 2478,6 & 2534,4 & 2576,4 & 2706,2 & 2940,1 & 3040,5 \\
\hline
\end{tabular}

Źródło: opracowanie własne na podstawie danych pochodzących z Głównego Urzędu Statystycznego (Bank Danych Lokalnych, dostęp: 26.02.2017, Roczne wskaźniki makroekonomiczne, dostęp: 26.02.2017).

Wydział Zarządzania UW ～DOI 10.7172/1733-9758.2017.24.8 
wśród gmin wiejskich zaobserwowano najwyższą dynamikę wzrostu poziomu własnego potencjału dochodowego. W okresie od 2007 roku do 2015 roku dochody realne gmin wiejskich wzrosły bowiem o blisko połowę, podczas gdy wśród gmin miejskich zaledwie o jedną piątą. Przyczyną wzrostu przeciętnego poziomu własnego potencjału dochodowego gmin wiejskich był między innymi wzrost potencjału demograficznego i gospodarczego wielu z nich, a szczególnie tych znajdujących się w bezpośrednim sąsiedztwie większych ośrodków miejskich na skutek zjawiska suburbanizacji. W rezultacie zmniejszyła się dysproporcja w zakresie poziomu własnego potencjału dochodowego gmin wiejskich w relacji do pozostałych typów gmin. W 2007 roku gminy wiejskie ogółem osiągały bowiem $62 \%$ przeciętnych dochodów własnych uzyskiwanych przez gminy miejskie, natomiast w 2015 roku już ponad $75 \%$ tych dochodów.

Należy jednak zwrócić uwagę, że gminy wiejskie są w bardzo wysokim stopniu zróżnicowane $\mathrm{w}$ zakresie pełnionych przez nie funkcji. Na ogół gmin wiejskich w Polsce składają się bowiem gminy będące sypialniami większych miast - tzw. metropolii, które zatraciły wiejski charakter, gminy będące kurortami nadmorskimi i górskimi - pełniące funkcje turystyczne, gminy wiejskie będące ośrodkami przemysłu na skalę krajową oraz gminy wiejskie o typowo rolniczym charakterze. $\mathrm{Z}$ badań przepro- wadzonych w ramach Monitoringu obszarów wiejskich (2016) wynika jednak, że większość gmin wiejskich wyróżnia nadal typowo rolniczy charakter. W rezultacie różnice pomiędzy wielkościami własnego potencjału dochodowego wśród gmin wiejskich są najwyższe (rysunek 1).

W badanym okresie nie zaobserwowano corocznego stabilnego wzrostu poziomu dochodów własnych wśród ogółu gmin wiejskich, jak i wśród pozostałych typów administracyjnych gmin. Konsekwencją kryzysu w systemie finansów lokalnych było bowiem zmniejszenie poziomu własnego potencjału dochodowego wszystkich podmiotów sektora samorządowego. Wśród gmin wiejskich wyraźne zmniejszenie dochodów własnych w 2009 roku w relacji do 2008 roku zaobserwowano w przypadku ponad $60 \%$ tych podmiotów. Uszczuplenie dochodów własnych gmin wiejskich wiązało się zwłaszcza z tymi źródłami, które uzależnione są od stanu koniunktury gospodarczej. Dotyczyło to zwłaszcza dochodów z tytułu udziałów gmin w podatku dochodowym od osób fizycznych oraz prawnych. Kryzys gospodarczy wpłynął więc na zmniejszenie poziomu samodzielności finansowej gmin wszystkich typów, a w szczególności w przypadku gmin miejsko-wiejskich. Biorąc pod uwagę wielkości przeciętne, w najmniejszym stopniu kryzys wpłynął na finanse gmin wiejskich, w przypadku których dochody nominalne zmniejszyły się o 1,4\% w 2009 roku w stosunku do 2008 roku. Wynikało to z faktu, że

Rysunek 1. Poziom dochodów własnych w złotych per capita w gminach wiejskich w Polsce w latach 2007-2015

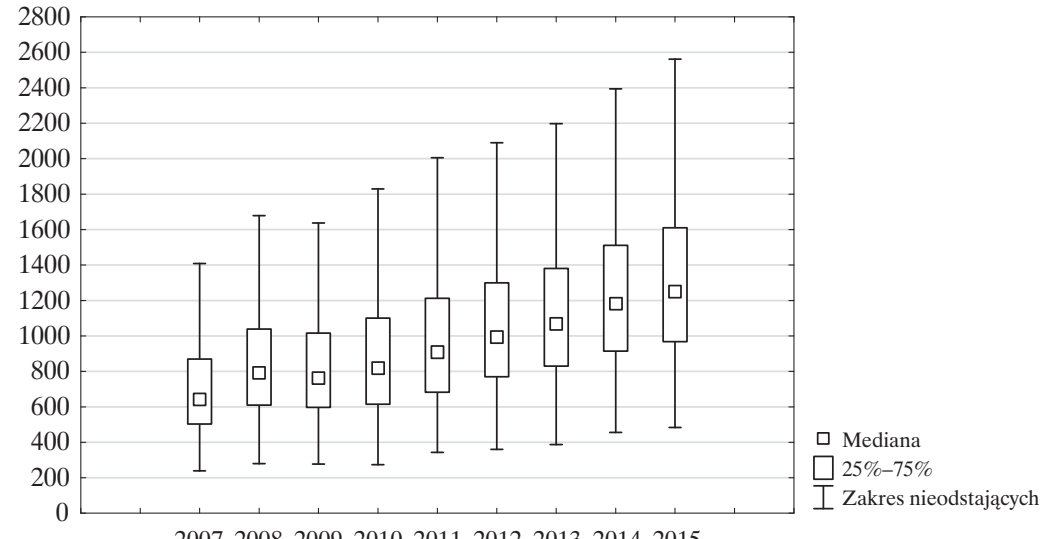

200720082009201020112012201320142015

Źródło: opracowanie własne na podstawie danych pochodzących z Głównego Urzędu Statystycznego (Bank Danych Lokalnych, dostęp: 26.02.2017). 
Tabela 2. Udział dochodów własnych w dochodach ogółem gmin w układzie typów administracyjnych w Polsce w latach 2007-2015 (\%)

\begin{tabular}{|l|l|c|c|c|c|c|c|c|c|c|}
\hline \multicolumn{2}{|c|}{ Wyszczególnienie } & $\mathbf{2 0 0 7}$ & $\mathbf{2 0 0 8}$ & $\mathbf{2 0 0 9}$ & $\mathbf{2 0 1 0}$ & $\mathbf{2 0 1 1}$ & $\mathbf{2 0 1 2}$ & $\mathbf{2 0 1 3}$ & $\mathbf{2 0 1 4}$ & $\mathbf{2 0 1 5}$ \\
\hline \multirow{3}{*}{ gminy } & wiejskie & 37,1 & 39,3 & 36,8 & 35,9 & 37,1 & 38,5 & 40,3 & 41,9 & 42,7 \\
\cline { 2 - 10 } & miejsko-wiejskie & 48,1 & 51,0 & 48,0 & 46,5 & 47,4 & 48,3 & 50,1 & 51,1 & 51,3 \\
\cline { 2 - 10 } & miejskiea) & 61,6 & 65,2 & 61,9 & 58,8 & 58,6 & 59,8 & 60,7 & 61,1 & 61,1 \\
\hline \multicolumn{2}{|l|}{ miasta na prawach powiatu } & 65,7 & 69,5 & 66,1 & 63,6 & 63,2 & 61,1 & 62,4 & 62,8 & 63,5 \\
\hline \multicolumn{2}{|l}{ metropolieb) } & 66,3 & 70,0 & 66,7 & 64,3 & 65,2 & 62,3 & 62,9 & 64,7 & 64,3 \\
\hline
\end{tabular}

a) bez miast na prawach powiatu.

b) obejmują miasta Białystok, Bydgoszcz, Gdańsk, Katowice, Kraków, Lublin, Łódź, Poznań, Rzeszów, Szczecin, Warszawa, Wrocław.

Źródło: opracowanie własne na podstawie danych pochodzących z Głównego Urzędu Statystycznego (Bank Danych Lokalnych, dostęp: 26.02.2017).

ważnym źródłem dochodów własnych wielu gmin wiejskich, które pełnią typowe funkcje rolnicze są nadal dochody $\mathrm{z}$ podatków rolnego i leśnego. Jak zauważa Poniatowicz (2014), źródła tych dochodów, obok dochodów $\mathrm{z}$ podatku od nieruchomości, należą do najmniej wrażliwych na zmiany stanu koniunktury gospodarczej źródeł dochodów.

Kryzys gospodarczy wpłynął na relację wskaźnika dochodów własnych do dochodów ogółem gmin, osłabiając znaczenie dochodów własnych, jednocześnie zwiększając w budżetach gmin rolę transferów $\mathrm{z}$ budżetu państwa. W warunkach kryzysu finansowego, tj. w 2009 roku, wśród gmin wiejskich zaobserwowano najniższą relacje dochodów własnych w dochodach ogółem, która wyniosła 36,8\% (była niższa o 2,5 pkt. proc. w stosunku do 2008 roku). W kolejnych latach, w warunkach poprawiającej się koniunktury gospodarczej poziom dochodów własnych gmin wiejskich sukcesywnie wzrastał i w 2015 roku stanowiły one już blisko $43 \%$ ogółu dochodów tych podmiotów. Niemniej jednak poziom samodzielności finansowej gmin wiejskich, kwantyfikowany udziałem dochodów własnych w dochodach ogółem, jest nadal znacznie niższy w stosunku do gmin pozostałych typów.

Kryzys niewątpliwie wpłynął negatywnie na wyniki budżetowe gmin, utrwalając

Tabela 3. Wynik finansowy budżetów gmin w układzie typów administracyjnych w Polsce w latach 2007-2015 (w mln zt)

\begin{tabular}{|c|c|c|c|c|c|c|c|c|c|c|c|}
\hline \multicolumn{2}{|c|}{$\begin{array}{l}\text { Wyszcze- } \\
\text { gólnienie }\end{array}$} & 2007 & 2008 & 2009 & 2010 & 2011 & 2012 & 2013 & 2014 & 2015 & $\begin{array}{c}\text { Suma } \\
2007-2015\end{array}$ \\
\hline \multirow{3}{*}{ 害 } & wiejskie & 50,6 & $-64,4$ & 719,0 & & & 256,4 & 338,9 & & 932,3 & $-5459,9$ \\
\hline & & 207,8 & $-323,9$ & $-1791,0$ & $-2517,6$ & $-1399,1$ & $-122,6$ & 93,6 & $-189,7$ & 511,6 & $-5531,0$ \\
\hline & miejskiea) & 370,6 & $-186,5$ & -1610 & & -722 & $-217,7$ & 168, & 52,1 & 278,9 & $-3343,1$ \\
\hline \multicolumn{2}{|c|}{$\begin{array}{l}\text { miasta } \\
\text { na prawach } \\
\text { powiatu }\end{array}$} & 996,3 & $-1728,6$ & $-5873,6$ & $-5068,6$ & $-4650,7$ & $-2483,8$ & $-736,0$ & $-1401,6$ & 735,9 & $-20210,5$ \\
\hline \multicolumn{2}{|c|}{ metropolieb) } & 665,6 & $-1312,3$ & $-3818,6$ & $-3358,7$ & $-3234,1$ & $-1889,1$ & $-173,8$ & $-365,9$ & 993,1 & $-12493,7$ \\
\hline
\end{tabular}

a) bez miast na prawach powiatu.

b) obejmują miasta Białystok, Bydgoszcz, Gdańsk, Katowice, Kraków, Lublin, Łódź, Poznań, Rzeszów, Szczecin, Warszawa, Wrocław.

Źródło: opracowanie własne na podstawie danych pochodzących z Głównego Urzędu Statystycznego (Bank Danych Lokalnych, dostęp: 26.02.2017).

Wydział Zarządzania UW DOI 10.7172/1733-9758.2017.24.8 
Rysunek 2. Wynik finansowy budżetów gmin wiejskich w Polsce w latach 2007-2015 (w zł)

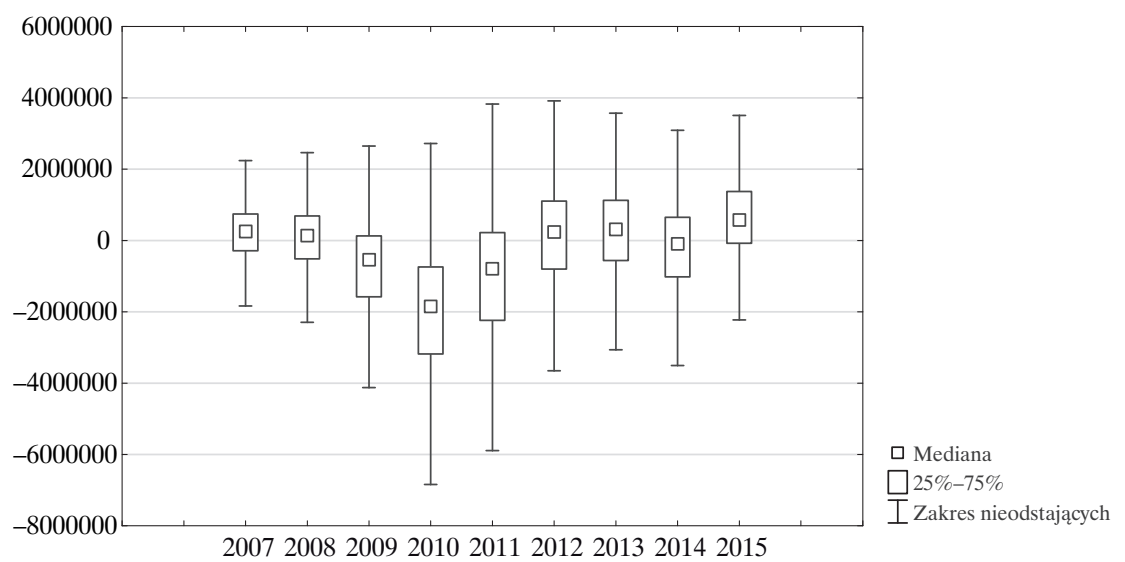

Źródło: opracowanie własne na podstawie danych pochodzących z Głównego Urzędu Statystycznego (Bank Danych Lokalnych, dostęp: 26.02.2017).

nierównowage fiskalną, przejawiajaccą się narastaniem deficytów budżetowych oraz pogorszeniem się wyników operacyjnych tych podmiotów (zmniejszeniem się nadwyżki operacyjnej lub zwiększeniem deficytu operacyjnego). Gwałtowne pogorszenie wyników finansowych zarówno gmin wiejskich, jak i pozostałych typów gmin zaobserwowano w latach 2009-2011, kiedy to łaczny deficyt budżetowy tych podmiotów był najwyższy. W przypadku gmin wiejskich najwyższy deficyt budżetowy odnotowano w 2010 roku i wyniósł on łącznie 3436,3 mln zł. W okresie od 2009 do 2011 roku w przypadku $70 \%$ ogółu gmin wiejskich odnotowano deficyt budżetowy (Bank Danych Lokalnych, 26.02.2017).

Ważnymi wyznacznikami stabilności finansowej JST są nie tylko ogólne, lecz także operacyjne wyniki budżetowe. $\mathrm{W}$ związku $\mathrm{z}$ wprowadzeniem indywidualnego podejścia do oceny zdolności kredytowej jednostek samorządowych szczególne znaczenie ma obecnie ocena wyników operacyjnych tych jednostek. Wielkość nadwyżki operacyjnej wpływa na możliwości zaciągania nowych zobowiązań oraz na zdolność do finansowania wydatków o charakterze inwestycyjnym. Wysokość nadwyżki operacyjnej jest podstawą do ustalania nowego wskaźnika zadłużenia który 2014 roku jest określany indywidualnie dla każdej JST. W latach 2007-2011 udział nadwyżki operacyjnej w dochodach ogółem gmin wszystkich typów obniżał się. Relatywnie najlepszą sytuacją finansową w zakresie wyniku bieżącego charakteryzowały się w badanych latach gminy wiejskie, bowiem średni udział nadwyżki operacyjnej w dochodach ogółem wyniósł w tych gminach prawie $10 \%$. Analizujac wyniki bieżące gmin, można ponadto zauważyć, że we wszystkich typach gmin po spadkach nadwyżki operacyjnej obserwowanych w latach 2007-2011, od 2012 roku sytuacja finansowa gmin uległa poprawie (tabela 4). Można przypuszczać, że sytuacja ta związana była z celowym działaniem wielu JST, mającym na celu wzrost indywidualnego wskaźnika zadłużenia obowiązującego, który zależy m.in. od poziomu nadwyżki operacyjnej z ostatnich trzech lat.

Zagrożeniem dla stabilności finansowej gmin może być dynamiczny wzrost poziomu ich zadłużenia i wysokie koszty obsługi długu. Przeprowadzone badania wykazały, że od 2007 roku do 2014 roku dynamicznie rosły zobowiązania zarówno gmin ogółem, jak i poszczególnych ich typów. Najwyższy poziom zadłużenia wśród samorządów gminnych wyróżniał gminy miejskie i miejsko-wiejskie, najniższy natomiast gminy wiejskie (tabela 5). W 2014 roku zadłużenie gmin miejskich i miejskowiejskich ogółem stanowiło przeciętnie odpowiednio 1 021,6 i 1 064,7 zł per capita i było o około $20 \%$ wyższe w relacji do gmin wiejskich. Należy jednak zauważyć, że gminy wiejskie wyróżniało najwyższe tempo zmian poziomu zadłużenia. W badanym okresie zadłużenie tych podmiotów wzro- 
Tabela 4. Wyniki bieżące budżetów w relacji do dochodów ogółem gmin w układzie typów -administracyjnych w Polsce w latach 2007-2014 (\%)

\begin{tabular}{|l|l|c|c|c|c|c|c|c|c|c|}
\hline \multicolumn{2}{|c|}{ Wyszczególnienie } & $\mathbf{2 0 0 7}$ & $\mathbf{2 0 0 8}$ & $\mathbf{2 0 0 9}$ & $\mathbf{2 0 1 0}$ & $\mathbf{2 0 1 1}$ & $\mathbf{2 0 1 2}$ & $\mathbf{2 0 1 3}$ & $\mathbf{2 0 1 4}$ & $\mathbf{2 0 1 5}$ \\
\hline \multirow{3}{*}{ gminy } & wiejskie & 13,5 & 14,4 & 12,1 & 8,7 & 8,5 & 9,6 & 10,8 & 10,8 & 10,8 \\
\cline { 2 - 11 } & miejsko-wiejskie & 11,6 & 11,7 & 8,6 & 5,4 & 6,6 & 7,4 & 8,5 & 9,0 & 9,8 \\
\cline { 2 - 11 } & miejskiea) & 12,4 & 12,0 & 6,0 & 3,8 & 5,5 & 5,7 & 6,9 & 8,0 & 8,5 \\
\hline miasta na prawach powiatu & 14,5 & 11,6 & 5,9 & 4,6 & 4,9 & 4,2 & 6,5 & 7,6 & 8,3 \\
\hline metropolieb) & 16,2 & 12,4 & 6,1 & 4,3 & 4,8 & 3,6 & 7,2 & 8,4 & 9,4 \\
\hline
\end{tabular}

a) bez miast na prawach powiatu,

b) obejmują miasta Białystok, Bydgoszcz, Gdańsk, Katowice, Kraków, Lublin, Łódź, Poznań, Rzeszów, Szczecin, Warszawa, Wrocław,

Źródło: opracowanie własne na podstawie danych pochodzących z Głównego Urzędu Statystycznego (Bank Danych Lokalnych, dostęp: 01.05.2017).

sło bowiem ponad trzykrotnie, $\mathrm{z}$ poziomu 267,7 zl per capita w 2007 roku do 859,1 zl per capita w 2014 roku (tabela 5). Najwyższą dynamikę wzrostu poziomu zadłużenia gmin zaobserwowano w latach 2009 i 2010. W przypadku gmin wiejskich poziom ich zadłużenia wzrósł o odpowiednio $31,5 \%$ i $70,3 \%$ w relacji do roku poprzedniego. Jedną z przyczyn wzrostu poziomu zadłużenia gmin była dekoniunktura gospodarcza i zmniejszenie poziomu własnego potencjału dochodowego gmin. Kolejnym czyn- nikiem wzrostu poziomu zadłużenia była niewątpliwie realizacja szeregu inwestycji współfinansowanych ze środków z Unii Europejskiej.

Należy podkreślić, że rosnące zadłużenie gmin nie zawsze oznacza zjawisko negatywne. W przypadku gdy zaciagane przez podmioty sektora samorządowego zobowiazania przeznaczane są na realizację inwestycji, wtedy występuje według Waligóry (2013) tzw. dobry dług. Przeprowadzone badania wykazały, że w latach 2007-2011,

Tabela 5. Poziom zadłużenia gmin w układzie typów administracyjnych w Polsce w latach 2007-2014 (w zł per capita)

\begin{tabular}{|c|c|c|c|c|c|c|c|c|c|c|}
\hline \multicolumn{2}{|c|}{$\begin{array}{l}\text { Wyszczegól- } \\
\text { nienie }\end{array}$} & 2007 & 2008 & 2009 & 2010 & 2011 & 2012 & 2013 & 2014 & $\begin{array}{c}\text { Średnio- } \\
\text { okresowe } \\
\text { tempo zmianc) }\end{array}$ \\
\hline \multirow{3}{*}{ 鸹 } & wiejskie & 330,9 & 352,7 & 463,8 & 790 & 944,1 & 926,3 & 926 & 859,1 & 14,6 \\
\hline & $\begin{array}{l}\text { miejsko- } \\
\text {-wiejskie }\end{array}$ & 435,9 & 461,7 & 616,8 & 929,2 & 1085,2 & 1091,2 & 1082,7 & 1064,7 & 13,6 \\
\hline & miejskiea) & 458,0 & 481,7 & 647,8 & 907,8 & 1036,0 & 1052,1 & 1036,5 & 1021,6 & 12,1 \\
\hline \multicolumn{2}{|c|}{$\begin{array}{l}\text { miasta } \\
\text { na prawach } \\
\text { powiatu }\end{array}$} & 746,8 & 792,3 & 1058,8 & 1362,9 & 1625,5 & 1758,3 & 1829,3 & 1958,2 & 14,8 \\
\hline \multicolumn{2}{|c|}{ metropolieb) $^{\text {b) }}$} & 918,9 & 1102,4 & 1587,7 & 1965,1 & 2467,5 & 2688,6 & 2805,1 & 2924,2 & 18,0 \\
\hline
\end{tabular}

a) bez miast na prawach powiatu,

b) obejmują miasta Białystok, Bydgoszcz, Gdańsk, Katowice, Kraków, Lublin, Łódź, Poznań, Rzeszów, Szczecin, Warszawa, Wrocław,

c) obliczone na podstawie wszystkich wyrazów szeregu czasowego (Wysocki i Lira, 2003).

Źródło: opracowanie własne na podstawie danych pochodzących z Ministerstwa Finansów (Wskaźniki do oceny sytuacji finansowej jednostek samorządu terytorialnego, dostęp: 26.02.2017). 
Rysunek 3. Poziom zadłużenia gmin w złotych per capita w gminach wiejskich w Polsce w latach 2007-2014

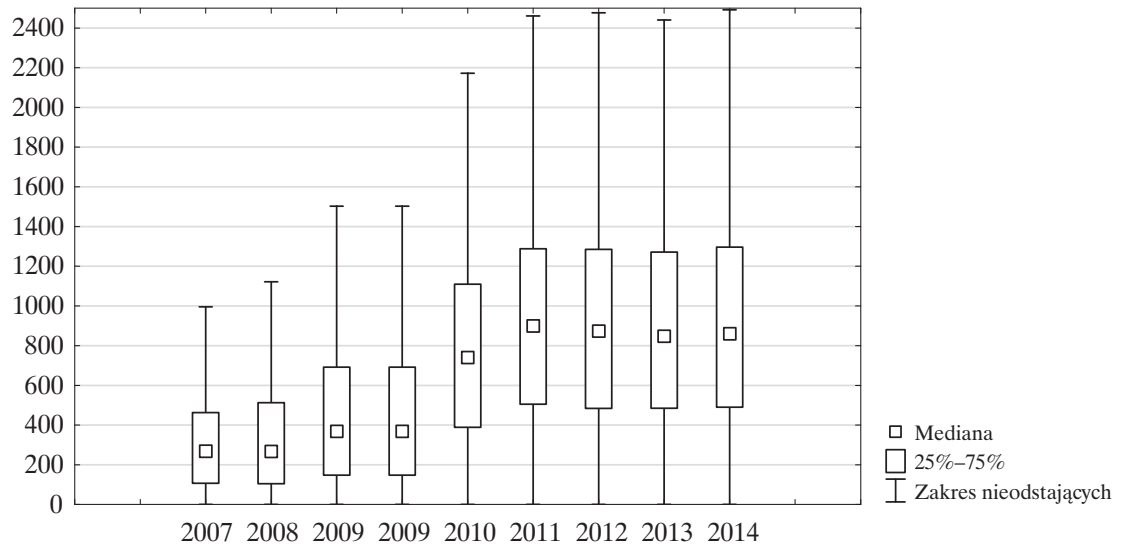

Źródło: opracowanie własne na podstawie danych pochodzących z Ministerstwa Finansów (Wskaźniki do oceny sytuacji finansowej jednostek samorządu terytorialnego, dostęp: 26.02.2017).

wraz ze wzrostem zadłużenia gmin wiejskich rosły systematycznie gminne wydatki inwestycyjne, co wiązało się także z wykorzystaniem środków pochodzących z Uni Europejskiej. Od 2012 roku w gminach wiejskich zaobserwowano jednak zahamowanie realizowanych inwestycji (tabela 7). Przyczyny ograniczenia wydatków inwestycyjnych przez samorządy gminne można szukać m.in. w spowolnieniu gospodarczym i jego oddziaływaniu na stan finansów samorządowych w postaci niższego poziomu uzyskiwanych dochodów własnych. Istotną przyczyną zahamowania inwestycji samorządowych mogła być także zmiana uregulowań prawnych dotyczących możliwości zaciągania nowych zobowiązań przez te podmioty od 2014 roku (wprowadzenie tzw. indywidualnego wskaźnika zadłużenia JST uwzględniającego sytuację finansową samorządu - art. 243 ustawy o finansach publicznych), co wymuszało wprowadzenie większej dyscypliny wydatkowej.

W badanym okresie nie tylko wzrósł ogólny poziom zadłużenia badanych podmiotów, ale także wzrosło zróżnicowanie gmin wiejskich w tym zakresie. Jednocześnie gminy wiejskie należą do grupy gmin o najwyższym stopniu zróżnicowania, jeżeli chodzi o poziom zadłużenia per capita. Sytuacja ta wynikać może ze znacznego zróżnicowania tych podmiotów pod kątem pełnionych przez nie funkcji. Ogólny wzrost poziomu zadłużenia gmin wiejskich przełożył się na wzrost przeciętnego poziomu wskaźnika udziału zobowiązań ogółem w dochodach ogółem, którego poziom $60 \%$ do końca 2013 roku wyznaczał dozwolony przez ustawodawcę pułap (art. 170 ustawy o finansach publicznych z 2005 r.). W 2014 roku udział zobowiązań w dochodach gmin wiejskich ogółem w Polsce stanowił 26,3\% i był o ponad 10 pkt. proc. wyższy w relacji do 2007 roku (tabela 6).

Wzrost poziomu długu determinuje wyższe koszty związane $\mathrm{z}$ jego obsługą. Barierą dla rozwoju lokalnego może być sytuacja, w której w konsekwencji kumulacji deficytów gmin z poprzednich lat, następuje eskalacja długu samorządowego. W rezultacie wśród gmin pojawić mogą się problemy z utrzymaniem płynności finansowej. Poprzez analize wielkości przecietnych w badaniach wykazano, że w polskich warunkach koszty obsługi długu w relacji do dochodów ogółem gmin w 2014 roku w stosunku do 2007 roku nie wzrosły drastycznie lub uległy zmniejszeniu i wciąż pozostają na umiarkowanym poziomie. W 2007 roku w przypadku gmin stanowiły one przeciętnie od $10 \%$ dla gmin miejskich do ponad $16 \%$ dochodów własnych dla gmin wiejskich i w 2014 roku pozostawały na analogicznym poziomie. Wysoki poziom obciążenia dochodów własnych gmin wydatkami na obsługe zadłużenia, zwłaszcza gmin wiejskich, zaobserwowano w ostatnich latach perspektywy finansowej 2007-2013, w których stanowily przeciętnie od $20 \%$ do $25 \%$ ogółu dochodów własnych (tabela 7, rysunek 4). 
Tabela 6. Udział zobowiązań ogółem w dochodach ogółem gmin w układzie typów administracyjnych w Polsce w latach 2007-2014 (\%)

\begin{tabular}{|c|c|c|c|c|c|c|c|c|c|c|}
\hline \multicolumn{2}{|r|}{ Wyszczególnienie } & 2007 & 2008 & 2009 & 2010 & 2011 & 2012 & 2013 & 2014 & $\begin{array}{c}\text { Zmiana } \\
\text { 2014/2007 } \\
\text { (w pkt. proc.) }\end{array}$ \\
\hline \multirow{3}{*}{ 賗 } & wiejskie & 14,4 & 13,8 & 17,2 & 26,9 & 30,6 & 28,8 & 27,8 & 26,3 & 11,9 \\
\hline & miejsko-wiejskie & 19,5 & 18,7 & 23,9 & 32,7 & 37,1 & 35,8 & 34,6 & 33,1 & 13,6 \\
\hline & miejskie a) & 19,6 & 19,5 & 25,8 & 32,4 & 35,6 & 35,5 & 33,6 & 31,7 & 12,1 \\
\hline \multicolumn{2}{|c|}{$\begin{array}{l}\text { miasta na prawach } \\
\text { powiatu }\end{array}$} & 22,8 & 22,8 & 30,1 & 34,7 & 39,2 & 39,7 & 39,9 & 40,4 & 17,6 \\
\hline \multicolumn{2}{|c|}{ metropolie b) } & 25,8 & 29,1 & 39,9 & 46,4 & 55,8 & 55 & 55 & 54,6 & 28,8 \\
\hline
\end{tabular}

a) bez miast na prawach powiatu,

b) obejmują miasta Białystok, Bydgoszcz, Gdańsk, Katowice, Kraków, Lublin, Łódź, Poznań, Rzeszów, Szczecin, Warszawa, Wrocław.

Źródło: opracowanie własne na podstawie danych pochodzących z Ministerstwa Finansów (Wskaźniki do oceny sytuacji finansowej jednostek samorządu terytorialnego, dostęp: 26.02.2017).

Tabela 7. Obciążenie dochodów ogółem i własnych wydatkami na obsługę długu w gminach wiejskich na tle pozostałych typów administracyjnych w Polsce w latach 2007-2014 (\%)

\begin{tabular}{|c|c|c|c|c|c|c|c|c|c|c|}
\hline \multicolumn{2}{|r|}{ Wyszczególnienie } & 2007 & 2008 & 2009 & 2010 & 2011 & 2012 & 2013 & 2014 & $\begin{array}{c}\text { Zmiana } 2014 / 2007 \\
\text { (w pkt. proc.) }\end{array}$ \\
\hline \multicolumn{11}{|c|}{ Obciążenie dochodów ogółem wydatkami na obsługę zadłużenia (\%) } \\
\hline \multirow{3}{*}{. } & wiejskie & 5,2 & 4,4 & 4,1 & 4,9 & 8,1 & 9,2 & 8,9 & 5,8 & 0,6 \\
\hline & miejsko-wiejskie & 6,2 & 5,5 & 5,0 & 5,9 & 8,0 & 9,4 & 9,7 & 5,7 & $-0,5$ \\
\hline & miejskiea) & 6,4 & 5,8 & 5,3 & 6,1 & 7,1 & 8,0 & 8,5 & 5,0 & $-1,4$ \\
\hline \multicolumn{2}{|c|}{$\begin{array}{l}\text { miasta na prawach } \\
\text { powiatu }\end{array}$} & 7,8 & 6,0 & 5,3 & 6,0 & 8,0 & 7,7 & 10,3 & 5,0 & $-2,8$ \\
\hline \multicolumn{2}{|c|}{ metropolieb) } & 6,1 & 5,6 & 5,6 & 7,3 & 8,3 & 8,3 & 7,4 & 6,2 & 0,1 \\
\hline \multicolumn{11}{|c|}{ Obciążenie dochodów własnych wydatkami na obsługę zadłużenia (\%) } \\
\hline \multirow{3}{*}{ 莺 } & wiejskie & 16,1 & 13,8 & 14,5 & 17,7 & 28,1 & 30,3 & 15,0 & 16,7 & 0,6 \\
\hline & miejsko-wiejskie & 15,0 & 13,3 & 13,2 & 15,9 & 21,3 & 24,2 & 23,3 & 13,2 & $-1,8$ \\
\hline & miejskie & 10,7 & 9,5 & 9,4 & 11,3 & 13,2 & 14,8 & 15,0 & 8,6 & $-2,1$ \\
\hline \multicolumn{2}{|c|}{$\begin{array}{l}\text { miasta na prawach } \\
\text { powiatu }\end{array}$} & 13,3 & 10,6 & 10,3 & 12,2 & 15,8 & 15,5 & 20,7 & 9,4 & $-3,9$ \\
\hline \multicolumn{2}{|c|}{ metropolie } & 8,8 & 8,1 & 8,6 & 11,6 & 11,6 & 13,7 & 11,9 & 9,7 & 0,9 \\
\hline
\end{tabular}

a) bez miast na prawach powiatu,

b) obejmują miasta Białystok, Bydgoszcz, Gdańsk, Katowice, Kraków, Lublin, Łódź, Poznań, Rzeszów, Szczecin, Warszawa, Wrocław.

Źródło: opracowanie własne na podstawie danych pochodzących z Ministerstwa Finansów (Wskaźniki do oceny sytuacji finansowej jednostek samorządu terytorialnego, dostęp: 26.02.2017). 
Rysunek 4. Obciążenie dochodów własnych wydatkami na obsługę zadłużenia w gminach wiejskich w Polsce w latach 2007-2014 (\%)

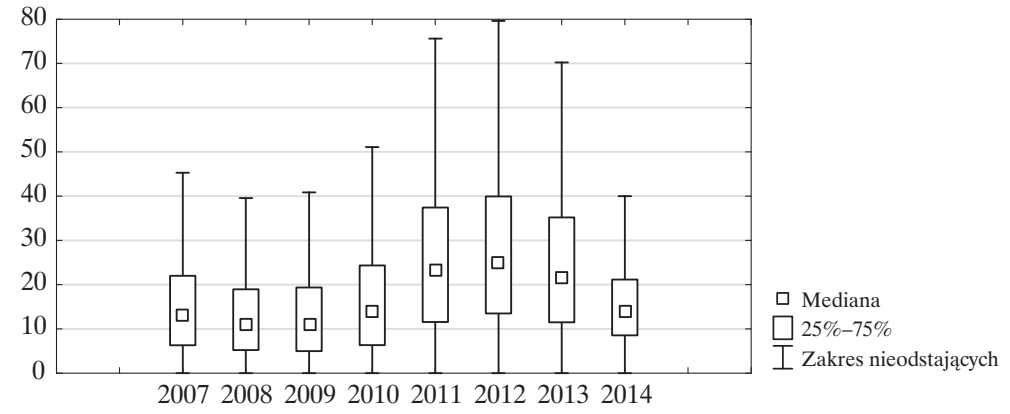

Źródło: opracowanie własne na podstawie danych pochodzących z Ministerstwa Finansów (Wskaźniki do oceny sytuacji finansowej jednostek samorządu terytorialnego, dostęp: 26.02.2017).

Wśród gmin wiejskich, o relatywnie niskim przeciętnym poziomie zadłużenia w relacji do pozostałych typów administracyjnych gmin, występuje ich duże zróżnicowanie w zakresie kosztów obsługi długu. W 2014 roku w przypadku relatywnie niewielkiego odsetka gmin wiejskich zaobserwowano brak obciążenia budżetów wydatkami na obsługę zadłużenia (51 gmin wiejskich, stanowiących zaledwie 3\% ogółu gmin tego typu), jednakże wśród ponad $10 \%$ gmin wiejskich udział wydatków na obsługę zadłużenia w dochodach ogółem stanowił ponad $10 \%$. Analizując natomiast obciążenie dochodów własnych bieżąca obsługa zadłużenia, widzimy, że wśród ponad $65 \%$ ogólu gmin wiejskich relacja ta wyniosła ponad $10 \%$ (Wskaźniki do oceny sytuacji finansowej...). Należy mieć na uwadze, że wysoki udział wydatków na obsługę długu w dochodach ogółem, a w szczególności w dochodach własnych gmin, $\mathrm{z}$ uwagi na ich charakter, stanowić może istotne zagrożenie dla zachowania stabilności finansowej oraz barierę dla rozwoju lokalnego. Wydatki związane $\mathrm{z}$ obsługą zadłużenia należy zaliczyć bowiem do tzw. wydatków sztywnych, które ograniczaja możliwość swobodnego kreowania polityki rozwoju lokalnego przez władze samorządowe.

W wyniku dynamicznego wzrostu poziomu zadłużenia głównymi problemami gmin wiejskich, a także pozostałych podmiotów sektora samorządowego mogą stać się rosnące koszty obsługi zadłużenia oraz relatywnie niska nadwyżka operacyjna (tabela 8). Wielkość nadwyżki operacyjnej gmin wpływa na możliwość zacią- gania przez nie nowych zobowiązań oraz na zdolność do finansowania wydatków o charakterze inwestycyjnym. Przeprowadzone badania wykazały, że w okresie od 2007 roku do 2014 roku wypracowana nadwyżka operacyjna gmin wiejskich ogółem stanowiła zaledwie 50,4\% wydatków inwestycyjnych. Pozostała część wydatków inwestycyjnych była więc finansowana z dochodów majątkowych i instrumentami dłużnymi. Dochody majątkowe są jednak zwykle ograniczonym źródłem finansowania, bowiem są uzależnione od posiadanego przez gminę majątku i od możliwości jego sprzedaży. Mogą być one w przyszłości wyczerpane w wyniku sprzedaży majątku. Należy zauważyć także, że gminy wiejskie charakteryzują się znacznie niższym poziomem posiadanego majątku $\mathrm{w}$ relacji do pozostałych typów gmin, tj. miejskich i miejsko-wiejskich.

Zgodnie $\mathrm{z}$ reguła zrównoważonego budżetu władze samorządowe nie powinny zaciagać zobowiąań w celu finansowania zadań bieżących. Celowość wykorzystania deficytu budżetowego nie zawsze odpowiada tej regule zadłużenia się samorządów. Analizując relację wysokości deficytu budżetowego gmin wiejskich w stosunku do zrealizowanych przez nie wydatków inwestycyjnych, można zauważyć, że była ona najwyższa w latach 2009-2011. Najwyższą średnią relację deficytu budżetowego w stosunku do wydatków inwestycyjnych $\mathrm{w}$ gminach wiejskich zaobserwowano w 2009 roku i wyniosła ona wówczas $37,1 \%$. Analizując budżety poszczególnych gmin wiejskich, można zauważyć, że w przypadku kilkunastu gmin, w szczególności w 2010 roku, 
Tabela 8. Nadwyżka operacyjna zrealizowania na tle wybranych zmiennych finansowych w gminach wiejskich w Polsce w latach 2007-2014 (w m/n zf)

\begin{tabular}{|c|c|c|c|c|c|c|c|c|c|}
\hline $\begin{array}{l}\text { Wyszczegól- } \\
\text { nienie }\end{array}$ & 2007 & 2008 & 2009 & 2010 & 2011 & 2012 & 2013 & 2014 & 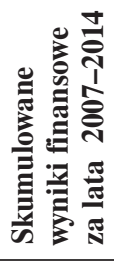 \\
\hline $\begin{array}{l}\text { Nadwyżka/defi- } \\
\text { cyt budżetowy }\end{array}$ & 350,6 & $-64,4$ & $-1719,0$ & $-3436,3$ & $-1735,0$ & 256,4 & 338,9 & $-383,5$ & $-6392,2$ \\
\hline $\begin{array}{l}\text { Nadwyżka } \\
\text { operacyjna }\end{array}$ & 3332,1 & 3902,1 & 3442,8 & 2776,4 & 2819,5 & 3293,5 & 3818,0 & 4005,4 & 27389,8 \\
\hline $\begin{array}{l}\text { Dochody } \\
\text { majątkowe }\end{array}$ & 1654,6 & 1494,8 & 1874,8 & 3115,9 & 3832,2 & 3326,5 & 2798,7 & 2924,8 & 21022,3 \\
\hline $\begin{array}{l}\text { w tym sprzedaż } \\
\text { sktadników } \\
\text { majątkowych }\end{array}$ & 191,0 & 148,4 & 86,9 & 70,0 & 73,4 & 71,9 & 77,8 & 66,1 & 785,3 \\
\hline $\begin{array}{l}\text { Wydatki } \\
\text { inwestycyjne }\end{array}$ & 4595,6 & 5403,6 & 6956,9 & 9267,3 & 8328,5 & 6291,8 & 6210,0 & 7244,9 & 54298,6 \\
\hline $\begin{array}{l}\text { Zadłużenie } \\
\text { ogółem }\end{array}$ & 2883,0 & 2888,7 & 3976,8 & 8081,4 & 9814,3 & 9576,6 & 9294,3 & 9436,4 & 55951,5 \\
\hline
\end{tabular}

Źródło: opracowanie własne na podstawie danych pochodzących z Głównego Urzędu Statystycznego (Bank Danych Lokalnych, dostęp: 26.02.2017) oraz Ministerstwa Finansów (Wskaźniki do oceny sytuacji finansowej jednostek samorządu terytorialnego, dostęp: 26.02.2017).

Tabela 9. Relacja deficytu budżetowego w relacji do zrealizowanych wydatków inwestycyjnych w Polsce w latach 2007-2014 (\%)a)

\begin{tabular}{|l|c|c|c|c|c|c|c|c|}
\hline \multicolumn{1}{|c|}{ Wyszczególnienie } & $\mathbf{2 0 0 7}$ & $\mathbf{2 0 0 8}$ & $\mathbf{2 0 0 9}$ & $\mathbf{2 0 1 0}$ & $\mathbf{2 0 1 1}$ & $\mathbf{2 0 1 2}$ & $\mathbf{2 0 1 3}$ & $\mathbf{2 0 1 4}$ \\
\hline $\begin{array}{l}\text { Relacja deficytu budżetowego w stosunku } \\
\text { do wydatków inwestycyjnych (\%) }\end{array}$ & $\times$ & 1,2 & 24,7 & 37,1 & 20,8 & $\times$ & $\times$ & 5,3 \\
\hline $\begin{array}{l}\text { Liczba podmiotów dla których relacja deficytu } \\
\text { budżetowego w stosunku do wydatków } \\
\text { inwestycyjnych przekroczyła 100\% }\end{array}$ & 7 & 8 & 17 & 41 & 11 & 3 & 2 & 5 \\
\hline
\end{tabular}

a) $\times$ oznacza brak deficytu budżetowego $\mathrm{w}$ danym typie podmiotów sektora samorządowego ogółem.

Źródło: obliczenia własne na podstawie danych pochodzących z Głównego Urzędu Statystycznego (Bank Danych Lokalnych, dostęp: 26.02.2017)

wskaźnik ten przekroczył poziom $100 \%$. Oznacza to, że zaciągnięte zobowiązania finansowały także wydatki bieżące gmin wiejskich.

\section{Podsumowanie i wnioski}

Analiza zjawiska stabilności finansowej gmin nie jest sprawa prosta $\mathrm{z}$ uwagi na wielowymiarowość tego zjawiska. Stabilność finansową $w$ odniesieniu do gmin rozpa- trywać można między innymi w kontekście stabilności źródeł ich dochodów własnych, jak również w zakresie zmian poziomu zjawiska zadłużenia. Przeprowadzone badania empiryczne w zakresie kształtowania się stabilności finansowej gmin wiejskich na tle pozostałych typów administracyjnych gmin wykazały, że:

- W 2015 roku w relacji do 2007 roku zaobserwowano wyraźny wzrost poziomu własnego potencjału dochodowego ogółu 
gmin wiejskich. W rezultacie w najwyższym stopniu zwiększył się poziom ich samodzielności finansowej, kwantyfikowany wielkością poziomu dochodów własnych per capita, z 849,7 zł do 1501,4 zł na mieszkańca, czyli o ponad $75 \%$.

- Konsekwencja kryzysu w systemie finansów lokalnych było zmniejszenie w 2009 roku w relacji do 2008 roku poziomu własnego potencjału dochodowego wszystkich podmiotów sektora samorządowego. Wśród gmin wiejskich wyraźne zmniejszenie dochodów własnych we wskazanym okresie wystąpiło w przypadku ponad $60 \%$ tych podmiotów. Biorąc jednakże pod uwagę wielkości przeciętne, w najmniejszym stopniu kryzys wpłynął na finanse gmin wiejskich, w przypadku których dochody nominalne zmniejszyły sie zaledwie o $1,4 \%$ w 2009 roku w stosunku do 2008 roku, podczas gdy wśród gmin miejskich i miejsko-wiejskich odpowiednio o 3,8\% i $2,3 \%$.

- Kryzys wpłynął negatywnie na wynik budżetowe gmin, utrwalając nierównowagę fiskalną, przejawiającą się narastaniem deficytów budżetowych oraz pogorszeniem się wyników operacyjnych tych podmiotów. Gwałtowne pogorszenie wyników finansowych zarówno gmin wiejskich, jak i pozostałych typów gmin zaobserwowano w latach 2009-2011, kiedy to łączny deficyt budżetowy tych podmiotów był najwyższy.

- Gminy wiejskie w latach 2007-2014 charakteryzował najniższy przeciętny poziom zadłużenia per capita, ale także najwyższe tempo jego zmian. $\mathrm{W}$ badanym okresie zadłużenie tych podmiotów wzrosło bowiem ponad trzykrotnie, z poziomu 267,7 zl per capita w 2007 roku do 859,1 zł per capita w 2014 roku. Pomimo wysokiej dynamiki wzrostu poziomu zadłużenia gmin wiejskich koszty obsługi długu w relacji do dochodów ogółem tych podmiotów w 2014 roku w stosunku do 2007 roku nie wzrosły drastycznie i wciąż pozostają na umiarkowanym poziomie. Gminy wiejskie są jednak w wysokim stopniu zróżnicowane w tym zakresie. Analizując obciążenie dochodów własnych bieżącą obsługą zadłużenia, aż wśród $65 \%$ ogółu gmin wiejskich relacja ta w 2014 roku wyniosła ponad $10 \%$. Wysoki udział wydatków na obsługę długu w docho- dach własnych gmin wiejskich, zwłaszcza tych o charakterze typowo rolniczym i o niskim poziomie samodzielności finansowej, $\mathrm{z}$ uwagi na ich charakter, stanowić może istotne zagrożenie dla zachowania stabilności finansowej tych podmiotów oraz barierę dla rozwoju lokalnego.

Przeprowadzone badania empiryczne wykazały, że stabilność finansowa gmin wiejskich, jak również innych typów administracyjnych gmin została zachwiana w latach 2009-2011, kiedy to zaobserwowano zmniejszenie lub też niską dynamikę zmian poziomu własnego potencjału dochodowego wielu gmin wiejskich, a także relatywnie wysoką dynamikę wzrostu poziomu ich zadłużenia. W związku z tym z uwagi na ważność kwestii bezpieczeństwa finansowego podmiotów sektora samorządowego, ze względu na rolę, jaką odgrywają w zaspokajaniu wielu potrzeb społeczności lokalnych, niezbędne jest prowadzenie dalszych pogłębionych badań majacych na celu dostarczenie informacji o czynnikach ryzyka dla jego stabilności.

\section{Przypisy}

1 Pojęcie bezpieczeństwa finansowego wiąże się nierozerwalnie $\mathrm{z}$ pojęciem stabilności finansowej. Oznacza to, że stabilność finansowa jest warunkiem bezpieczeństwa finansowego, jak również że bezpieczeństwo finansowe jest warunkiem stabilności finansowej.

2 Pierwszy z nich określał, że limit spłat z tytułu kredytów i pożyczek wraz z odsetkami, wykupu wyemitowanych przez jednostkę papierów wartościowych wraz $\mathrm{z}$ odsetkami i dyskontem oraz zobowiązań wynikających z udzielonych poręczeń i gwarancji nie mógł przekroczyć 15\% planowanych na dany rok budżetowy dochodów samorządu. W przypadku drugiego limitu łączna kwota długu JST na koniec roku budżetowego nie mogła przekroczyć $60 \%$ wykonanych dochodów ogółem tej jednostki w danym roku budżetowym (Poniatowicz, Salachna i Perło, 2010).

3 Indywidualny wskaźnik zadłużenia JST stanowi, że w danym roku budżetowym wartość spłaty zobowiązań wraz z kosztami ich obsługi do dochodów ogółem budżetu JST nie może przekroczyć średniej arytmetycznej z obliczonych dla ostatnich trzech lat relacji jej dochodów bieżących, powiekkszonych o dochody ze sprzedaży majątku oraz pomniejszonych o wydatki bieżące do dochodów ogółem budżetu (Ustawa z dnia 27 sierpnia 2009 r. o finansach publicznych, Dz.U. z 2013 r., poz. 885 z późn. zm.). 


\section{Bibliografia}

Alińska, A. i Wasiak, K. (2014). Czy stabilność systemu finansowego można uznać za dobro publiczne. Studia Ekonomiczne, 198, cz. 1, Wydawnictwo Uniwersytetu Ekonomicznego w Katowicach, 13-30.

Avoiding local government financial crisis: the role of state oversight (2000). Citizens Research Council of Michigan (CRCM). A publication of the Citizens Research Council of Michigan, Report No. 329.

Bank Danych Lokalnych. Główny Urząd Statystyczny, Warszawa (www.stat.gov.pl/bdl).

Bański, J. (2014). Perspektywy rozwoju polskiej wsi - wybrane zagadnienia. Wieś $i$ Rolnictwo, 4(165).

Bieniasz, A. i Czerwińska-Kayzer, D. (2016). Bezpieczeństwo finansowe przedsiębiorstw przemysłu spożywczego w Polsce. Journal od Agribusiness and Rural Development, 2(40), 239-247.

Bieniasz, A., Gołaś, Z. i Łuczak, A. (2014). Wielowymiarowa analiza kondycji finansowej gmin wiejskich w Polsce w latach 2007-2011. Wieś i Rolnictwo, 2(163), 101-121.

Clark, T.N. (2004). Municipal fiscal strain: indicators and causes. Government Finance Review (www. findarticles.com).

Crockett, A. (1997). Why is Financial Stability a Goal pf Public Policy? In: Maintaining Financial Stability in a Global Economy. Symposium Proceedings, Federal Reserve Bank of Kansas City, August, 55-96.

Dylewski, M. (2016). Stabilność finansowa jednostek samorządu terytorialnego u progu nowe perspektywy finansowej Unii Europejskiej. W: W. Jarmołowicz (red.), Gospodarka i finanse wobec wyzwań przysztości. Poznań: Wydawnictwo Wyższej Szkoły Bankowej w Poznaniu.

Filipiak, B. (2011). Finanse samorzqdowe - nowe wyzwania bieżace $i$ perspektywiczne. Warszawa: Difin.

Filipiak, B. (2015). Polityka podatkowa gmin czy realizacja władztwa podatkowego? Finanse, Rynki Finansowe, Ubezpieczenia, 76, t. 1, 221-230.

Filipiak, B. (2016). Wykorzystanie statystyki publicznej do oceny stabilności finansowej jednostek samorządu terytorialnego. Wiadomości Statystyczne, 11(666), 13-33.

Flejterski, S., Bielawska, A., Lubińska, T. i Swiecka, B. (2012). Stabilność rynkowego i publicznego systemu finansowego w erze niestabilności. W: A. Alińska (red.), Eseje o stabilności finansowej - Ksiega Jubileuszowa 45 lat pracy naukowej prof. dr hab. Bogustawa Pietrzaka. CeDeWu.pl.

Gospodarka finansowa jednostek samorzadu terytorialnego 2014 (2015). Warszawa: Główny Urząd Statystyczny.

Griffith-Jones, S. (2003). International Financia Stability and Market Efficiency as a Global Public
Good. W: K. Inge, P. Conceicao, K. Le Goulven i R. Mendoza (red.), Providing Global Public Goods. New York: Oxford University Press.

Hadyński, J. (2015). Regionalna konkurencyjność obszarów wiejskich. Poznań: Wydawnictwo Uniwersytetu Przyrodniczego w Poznaniu.

Heffner, K. i Klemens, B. (red.) (2016). Obszary wiejskie: wiejska przestrzeń i ludność, aktywność spoteczna i przedsiębiorczość. Polska Akademia Nauk, Komitet Przestrzennego Zagospodarowania Kraju. Jastrzębska, M. (2009). Ograniczenia zadłużenia jednostek samorzadu terytorialnego w świetle spełnienia przez Polskę kryteriów fiskalnych konwergencji. Finanse Komunalne, 4.

Klank, L. (2014). Stabilność finansowa jednostek samorząu terytorialnego. W: J. Solarz i E. Klamut (red.), Teoria stabilności finansowej. Test praktyki XXI wieku. Przedsiębiorczość i Zarzadzanie, tom 15, zeszyt 9, część 3 .

Kloha, P., Weissert, C.S. i Kleine, R. (2005). Developing and testing a composite model to predict local fiscal distress. Public Administration Review, 65(3).

Korolewska, M. i Marchewka-Bartkowiak, K (2011). Zadłużenie samorządów terytorialnych w Polsce. Studia BAS, 4(28).

Kozera, A., Głowicka-Wołoszyn, R. i Wysocki, F (2016). Samodzielność finansowa gmin wiejskich w woj. wielkopolskim. Wiadomości Statystyczne, 2, 73-86.

Kozera, A., Stanisławska, J. i Głowicka-Wołoszyn, R. (2016). Financial security of Polish households Journal od Agribusiness and Rural Development, 3(41), 319-328.

Kozera, A. i Wysocki, F. (2015). Typ funkcjonalny a samodzielność finansowa gmin wiejskich województwa wielkopolskiego. Roczniki Naukowe Stowarzyszenia Ekonomistów Rolnictwa i Agrobiznesu, tom XVII, zeszyt 6, 133-139.

Lubińska, T., Franek, S. i Bedzieszak, M. (2007) Potencjat dochodowy samorzadu $w$ Polsce na tle zmian ustawy o dochodach jednostek samorzadu terytorialnego. Warszawa: Difin.

Mishkin, F. (2000). Financial Stability and the Macroeconomy. Central Bank of Iceland Working, Paper No. 9, May.

Monitoring rozwoju obszarów wiejskich - Etap II (2016). Warszawa: Fundacja Europejski Fundusz Rozwoju Wsi i Rolnictwa, Instytut Rozwoju Wsi i Rolnictwa PAN.

Poniatowicz, M. (2014). Wptyw kryzysu gospodarczego na systemy finansowe jednostek samorzadu terytorialnego: na przykładzie największych miast w Polsce. Warszawa: CeDeWu.

Poniatowicz, M. (2016). Stabilność finansowa jednostek samorządu terytorialnego w aspekcie nowej 
perspektywy finansowej Unii Europejskiej i zmian w systemie dochodów samorządowych. W: Wyzwania Unii Europejskiej a stabilność finansów samorządowych. Ekonomiczne Problemy Ustug, 125.

Poniatowicz, M., Salachna, M. i Perło, D. (2010). Efektywne zarzadzanie dtugiem w jednostce samorzadu terytorialnego. Warszawa: Wolters Kluwer Polska.

Przygodzka, R. (2014). Władztwo podatkowe a stabilność finansowa gmin. Nierówności Spoteczne a Wzrost Gospodarczy, 40(4), 334-343.

Raport o stabilności systemu finansowego - grudzień 2016 (2016). Warszawa: Narodowy Bank Polski.

Roczne wskaźniki makroekonomiczne. Warszawa: Główny Urząd Statystyczny. Pobrano z: http:/ stat.gov.pl/wskazniki-makroekonomiczne/ (dostęp: 23.01.2017)

Romanowicz, B. (2014). Wpływ indywidualnego wskaźnika zadłużenia jednostek samorządu terytorialnego na poziom zadłużenia wybranych gmin województwa podkarpackiego. Nierówności Spoteczne a Wzrost Gospodarczy, 40(4).

Rosner, A., Stanny, M. (2016). Monitoring rozwoju obszarów wiejskich. Etap II. Przestrzenne zróżnicowanie poziomu rozwoju spoteczno-gospodarczego obszarów wiejskich. Warszawa: Fundacja Europejski Fundusz Rozwoju Wsi Polskiej, Instytut Rozwoju Wsi i Rolnictwa PAN

Trussel, J.M. i Patric, P.A. (2009). A predictive model of fiscal distress in local governments. Journal of Public Budgeting, Accounting \& Financial Management, 21(4), 578-616.

Ustawa z dnia 27 sierpnia 2009 roku o finansach publicznych, Dz.U. z 2013 r., poz. 885 z późn. zm.

Wskaźniki do oceny sytuacji finansowej jednostek samorzadu terytorialnego 2007-2009. Warszawa: Ministerstwo Finansów. Pobrano z: http://www. finanse.mf.gov.pl/budzet-panstwa/finanse-samorzadow/opracowania.

Wskaźniki do oceny sytuacji finansowej jednostek samorzadu terytorialnego 2010-2012. Warszawa: Ministerstwo Finansów. Pobrano z: http://www. finanse.mf.gov.pl/budzet-panstwa/finanse-samorzadow/opracowania.

Wskaźniki do oceny sytuacji finansowej jednostek samorzadu terytorialnego 2012-2014. Warszawa: Ministerstwo Finansów. Pobrano z: http://www. finanse.mf.gov.pl/budzet-panstwa/finanse-samorzadow/opracowania. 